\title{
Comparative genome analysis and genome- guided physiological analysis of Roseobacter litoralis
}

Daniela Kalhoefer ${ }^{1}$, Sebastian Thole ${ }^{1}$, Sonja Voget ${ }^{2}$, Rüdiger Lehmann², Heiko Liesegang ${ }^{2}$, Antje Wollher ${ }^{2}$, Rolf Daniel ${ }^{2}$, Meinhard Simon ${ }^{1}$ and Thorsten Brinkhoff ${ }^{*}$

\begin{abstract}
Background: Roseobacter litoralis OCh149, the type species of the genus, and Roseobacter denitrificans OCh114 were the first described organisms of the Roseobacter clade, an ecologically important group of marine bacteria. Both species were isolated from seaweed and are able to perform aerobic anoxygenic photosynthesis.

Results: The genome of $R$. litoralis OCh149 contains one circular chromosome of 4,505,211 bp and three plasmids of 93,578 bp (pRLO149_94), 83,129 bp (pRLO149_83) and 63,532 bp (pRLO149_63). Of the 4537 genes predicted for $R$. litoralis, $1122(24.7 \%)$ are not present in the genome of $R$. denitrificans. Many of the unique genes of $R$. litoralis are located in genomic islands and on plasmids. On pRLO149_83 several potential heavy metal resistance genes are encoded which are not present in the genome of $R$. denitrificans. The comparison of the heavy metal tolerance of the two organisms showed an increased zinc tolerance of $R$. litoralis. In contrast to $R$. denitrificans, the photosynthesis genes of $R$. litoralis are plasmid encoded. The activity of the photosynthetic apparatus was confirmed by respiration rate measurements, indicating a growth-phase dependent response to light. Comparative genomics with other members of the Roseobacter clade revealed several genomic regions that were only conserved in the two Roseobacter species. One of those regions encodes a variety of genes that might play a role in host association of the organisms. The catabolism of different carbon and nitrogen sources was predicted from the genome and combined with experimental data. In several cases, e.g. the degradation of some algal osmolytes and sugars, the genome-derived predictions of the metabolic pathways in $R$. litoralis differed from the phenotype.

Conclusions: The genomic differences between the two Roseobacter species are mainly due to lateral gene transfer and genomic rearrangements. Plasmid pRLO149_83 contains predominantly recently acquired genetic material whereas pRLO149_94 was probably translocated from the chromosome. Plasmid pRLO149_63 and one plasmid of $R$. denitrifcans (pTB2) seem to have a common ancestor and are important for cell envelope biosynthesis. Several new mechanisms of substrate degradation were indicated from the combination of experimental and genomic data. The photosynthetic activity of $R$. litoralis is probably regulated by nutrient availability.
\end{abstract}

\section{Background}

The genus Roseobacter comprises the two species Roseobacter litoralis OCh149 and Roseobacter denitrificans OCh114. Both species were isolated from marine seaweed and were the first described organisms of the Roseobacter clade [1]. $R$. denitrificans is able to grow anaerobically using nitrate or trimethyl-N-oxide (TMAO) as electron

\footnotetext{
* Correspondence: t.brinkhoff@icbm.de

'Institute for Chemistry and Biology of the Marine Environment, University of Oldenburg, Carl-von-Ossietzky-Straße 9-11, 26129 Oldenburg, Germany Full list of author information is available at the end of the article
}

acceptors [1-3], whereas $R$. litoralis showed no denitrifying activity [1]. R. denitrificans and R. litoralis as well as some other members of the clade have the ability to use light energy and perform aerobic anoxygenic photosynthesis $[1,4]$. In $R$. litoralis, the photosynthesis genes are located on a plasmid, which is unusual for aerobic anoxygenic phototrophs (AAnPs) [5].

The genome sequences of more than 40 Roseobacter clade members are available, but only five of them are finished [6]. The genome sequence of Roseobacter denitrificans OCh114 was published in 2007 by Swingley

\section{() Biomed Central}


and co-workers [7] and was the first genome of an aerobic anoxygenic phototrophic bacterium. The absence of ribulose bisphosphate carboxylase and phosphoribulokinase supports the assumption that AAnPs do not fix carbon dioxide via the Krebs-Cycle. Genes coding for other anaplerotic enzymes were found in the genome of $R$. denitrificans and the importance of mixotrophic growth was evident [7].

Plasmid-encoded functions are of great interest in genome analysis because plasmids often provide exchangeable niche specific fitness factors. Heavy metal resistances, e.g., are often encoded by plasmids [8,9] and are important for marine organisms as heavy metals accumulate in sediments $[10,11]$, in macroalgae [12-14] but also in other aquatic organisms [15]. Consequently, many of the sequenced Roseobacter clade members harbour plasmids, but due to the fact that the majority of the sequences are not finished, not much is known about these plasmids. However, it is assumed that translocation processes between chromosomes and plasmids occur frequently [16].

The aims of our study were the genome characterization, comparative genomics and genome-guided physiological analysis of $R$. litoralis, the type strain of the genus Roseobacter. The genome of $R$. litoralis was compared to the genome of the closely related $R$. denitrificans as well as to 38 genomes of other members of the Roseobacter clade. Metabolic pathways were reconstructed and verified by physiological tests. Heavy metal tolerance tests with both Roseobacter species were performed to confirm differences of the species indicated by genomic data. Furthermore, insights into the regulation mechanism of the photosynthetic activity of $R$. litoralis are given.

\section{Results and discussion}

General genomic features and comparison of the two Roseobacter species

The manually curated and annotated final genome sequence of $R$. litoralis OCh149 comprises a chromosome with the size of $4,505,211 \mathrm{bp}$ and three plasmids of 93,578 bp (pRLO149_94), 83,129 bp (pRLO149_83) and 63,532 bp (pRLO149_63), respectively (Table 1, Figures 1 and 2). The genome encodes 4537 predicted genes. The average $\mathrm{G}+\mathrm{C}$ content of the genome is $57.23 \%$. According to reciprocal BLAST analysis, the two Roseobacter species share a core genome consisting of 3415 genes $(75.3 \%$ of the genes of $R$. litoralis). The chromosomes of the two organisms have been subject to many genomic rearrangements that are evident in the chromosomal alignment (Figure 3). Of the 1122 unique genes $(24.7 \%)$ of $R$. litoralis, 226 are located on plasmids. In $R$. denitrificans, 714 (17.3\%) genes are unique of which 148 are plasmid-encoded. Many of the unique genes on the chromosomes occur in genomic islands (GEIs), but a variety of species-specific genes are scattered over the chromosomes. According to Clusters of Orthologous Groups (COG) -categories, the majority of these genes are involved in amino acid and carbohydrate metabolism. The unique genes with assigned function of $R$. litoralis and $R$. denitrificans are listed in Additional File 1.

\section{Genomic islands}

Ten GEIs were identified on the chromosome of $R$. litoralis (Figure 1, tagged with Arabic numerals) making up $\sim 665 \mathrm{~kb}(14.8 \%)$. In $R$. denitrificans, in contrast, only $\sim 300 \mathrm{~kb}(7.1 \%)$ were identified as genomic islands. The excess of $365 \mathrm{~kb}$ of alien genetic material in $R$. litoralis corresponds to the larger chromosome size $(\sim 372 \mathrm{~kb}$, see also Table 1) of the organism. Thus, the additional genetic material of $R$. litoralis was most likely acquired via horizontal gene transfer.

Typically, GEIs contain a $\mathrm{G}+\mathrm{C}$ content and a Codon Adaptation Index (CAI) different from the average [17]. Furthermore, transposases within the islands and tRNAs flanking the GEIs are indicators for translocation processes $[17,18]$. Many of the genes located in GEIs are of unknown function and several do not exhibit significant similarities to other genes in the databases (orphan genes). These orphan genes are thought to be phagederived genetic material [19]. Although no complete prophages are present in the genome of $R$. litoralis, in some of the islands phage-like genes were identified, e.g. in island 8 three putative phage tail proteins are located (RLO149_c037250 - RLO149_c037270).

In other GEIs, however, genes were identified that were probably derived from other bacterial species. Frequently, amino acid and carbohydrate transport and metabolism genes are present in the GEIs, providing $R$. litoralis with additional abilities for substrate utilization. For example island 5 contains genes for rhamnose transport and degradation (RLO149_c023060 - RLO149_ c023140) that have been described in Rhizobia [20]. Genes involved in nitrogen metabolism were identified in islands 1, 6 and 9 including different amidases (RLO149_c009550, RLO149_c040080, RLO149_c040170, RLO149_c028370), a second uncommon urease gene cluster (RLO149_c028310 - RLO149_c028360) and assimilatory nitrite and nitrate reductases (RLO149_ c039830 - RLO149_c039850). Island 4 contains a carbon monoxide dehydrogenase encoding gene $(\mathrm{CODH}$, RLO149_c017450 - RLO149_c017470), which is not present in $R$. denitrificans. The carbon monoxide dehydrogenase was believed to be common in the Roseobacter clade, as all members contain the corresponding genes [21-23]. However, recently it was shown that only a small proportion of Roseobacter clade members, among 
Table 1 General features of the genomes of $\boldsymbol{R}$. litoralis and $\boldsymbol{R}$. denitrificans

\begin{tabular}{|c|c|c|c|c|c|}
\hline R. litoralis & chromosome RL0149c & pRLO149_94 & pRLO149_83 & pRL0149_63 & \\
\hline Size $[b p]$ & $4,505,211$ & 93,578 & 83,129 & 63,532 & \\
\hline Protein coding sequences & 4,311 & 86 & 93 & 47 & \\
\hline Pseudogenes & 77 & & & 14 & \\
\hline $\mathrm{G}+\mathrm{C}$ content $[\%]$ & 57 & 58 & 59 & 55 & \\
\hline rRNA operons & 1 & & & & \\
\hline tRNAs & 37 & & & & \\
\hline R. denitrificans & chromosome & pTB1 & pTB2 & pTB3 & pTB4 \\
\hline Size $[b p]$ & $4,133,097$ & 106,469 & 69,269 & 16,575 & 5,824 \\
\hline Protein coding sequences & 3,946 & 105 & 56 & 16 & 6 \\
\hline Pseudogenes & 20 & 1 & & & \\
\hline $\mathrm{G}+\mathrm{C}$ content [\%] & 58 & 55 & 59 & 55 & 55 \\
\hline rRNA operons & 1 & & & & \\
\hline tRNAs & 38 & & & & \\
\hline
\end{tabular}

Data for R. denitrificans according to the NCBI database [96].

those $R$. litoralis, are able to oxidise carbon monoxide and that a wide variety lacks an essential subunit of the CODH-complex [24]. $R$. denitrificans is not able to oxidise carbon monoxide, but instead, has genes coding for a nitrate reductase that enables the organism to reduce nitrate under anaerobic growth conditions. Island 8 contains genes for coenzyme PQQ biosynthesis (RLO149_c036920 - RLO149_c036960) that are also located in a GEI of $R$. denitrificans. In island 10, genes for antigen biosynthesis were identified, e.g. UDP$\mathrm{N}$-acetylglucosamine 2-epimerase WecB (RLO149_ c044390) and UDP-4-amino-4-deoxy-L-arabinoseoxoglutarate aminotransferase ArnB (RLO149_c044340). The latter is also similar to the perosamine synthetase from Brucella melitensis, with GDP-perosamine being part of the O-antigen of the organism [25]. Antigens are polysaccharides and lipopolysaccharides that define the structure of the bacterial cell surface. Genes important for cell envelope biosynthesis are often found in islands of environmental bacteria [26]. The cell surface structure is important for biofilm formation and host association of the organisms and structural alteration can provide niche adaption and phage defence [19,26-28].

\section{Unique genes on plasmids}

Several species-specific genes, of which the majority is associated with heavy metal resistance (Table 2), are located on plasmid pRLO149_83. Therefore, the two Roseobacter species were compared with respect to zinc and copper tolerance. $R$. litoralis showed a higher tolerance of zinc, whereas $R$. denitrificans showed a higher copper tolerance. $R$. litoralis could grow without impairment up to $0.08 \mathrm{mM}$ of zinc, but was inhibited in its growth in the presence of low copper concentrations (0.04 mM). In contrast, $R$. denitrificans could not grow with $0.02 \mathrm{mM}$ zinc added to the medium, but was able to grow with $0.1 \mathrm{mM}$ of copper. The higher zinc tolerance of $R$. litoralis could be due to the $\mathrm{Zn}$-Cpx-type ATPase and/or the putative cobalt-zinc-cadmium resistance protein $\mathrm{CzcD}$ (Table 2), a member of the cation diffusion efflux (CDF) family [29]. Substrates of CDF proteins can be various cations [29], but mainly $\mathrm{Zn}^{2}$ ${ }^{+}$-transporting CDFs such as ZitB from Escherichia coli [30] are also known.

Most of the other putative heavy metal resistance genes on plasmid pRLO149_83 have weak similarities to known copper and silver efflux proteins (Table 2). But since no higher copper tolerance of $R$. litoralis compared to $R$. denitrificans was observed, the efflux systems might be involved in transport of other cations. Two other members of the Roseobacter clade, Dinoroseobacter shibae DFL-12 and Roseovarius nubinhibens ISM, have orthologous heavy metal resistance genes on their plasmids (Figure 2B).

Plasmids are important mobile genetic elements and therefore often contain recently acquired genetic material. Thus, the occurrence of species-specific and also alien genes on two of the plasmids (Figure 2B and $2 \mathrm{C}$ ) was not surprising. Plasmid pRLO149_94, however, is an exception as no alien genes or genomic islands were identified on the plasmid. Nearly the entire genetic information of pRLO149_94 was found on the chromosome of $R$. denitrificans, with approximately $78 \mathrm{~kb}$ being syntenic. Also in $R$. denitrificans the area was not identified as GEI. Only nine ORFs on the plasmid are not present in the genome of $R$. denitrificans. The genes for the photosynthetic apparatus comprise $\sim 45 \mathrm{~kb}$ and are part of the syntenic area with the plasmid replication genes located amidst the photosynthesis genes in $R$. litoralis (Figure 2A). The remaining $33 \mathrm{~kb}$ that are syntenic in both organisms are located upstream of the photosynthesis genes in $R$. denitrificans and encode other functions. 


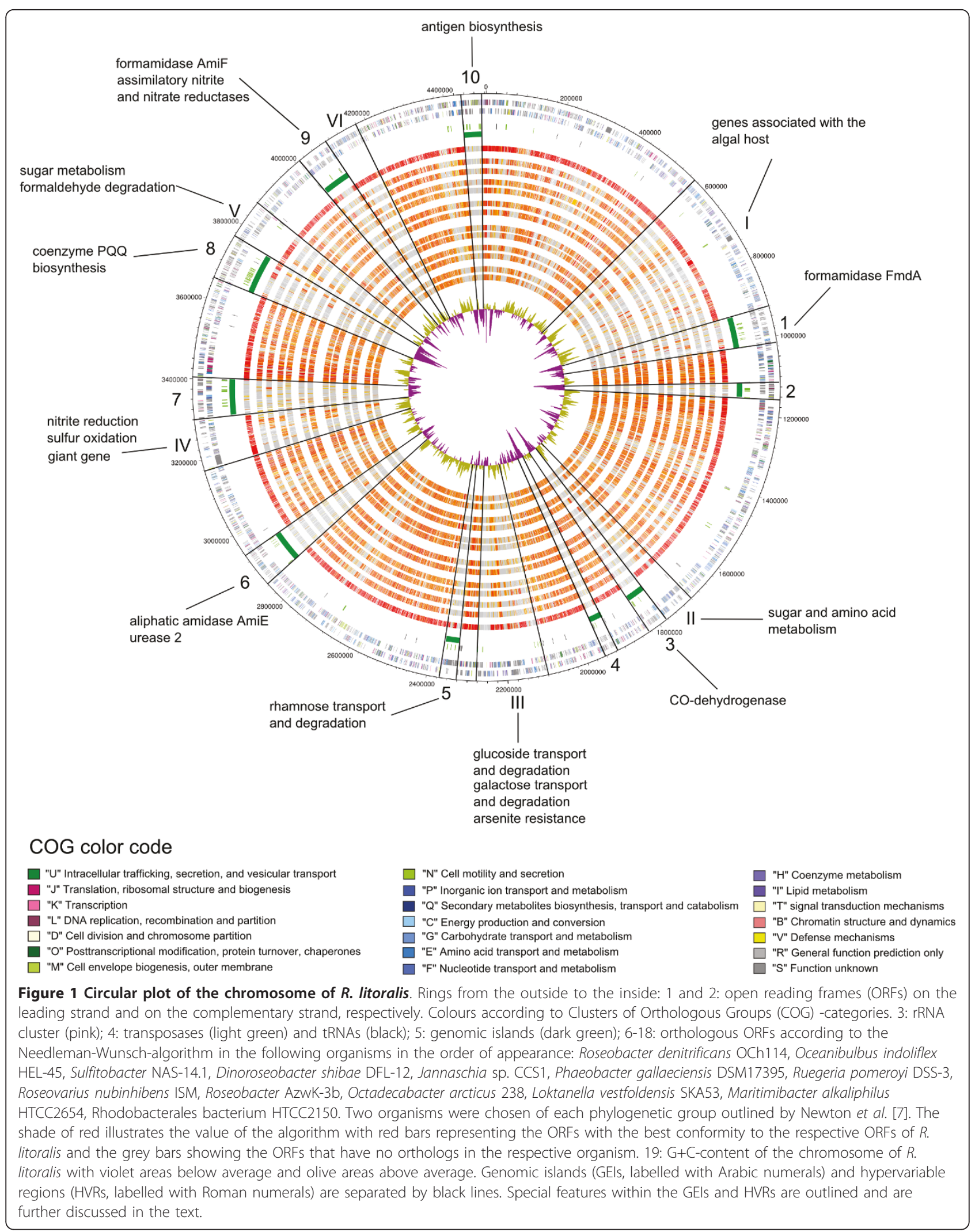



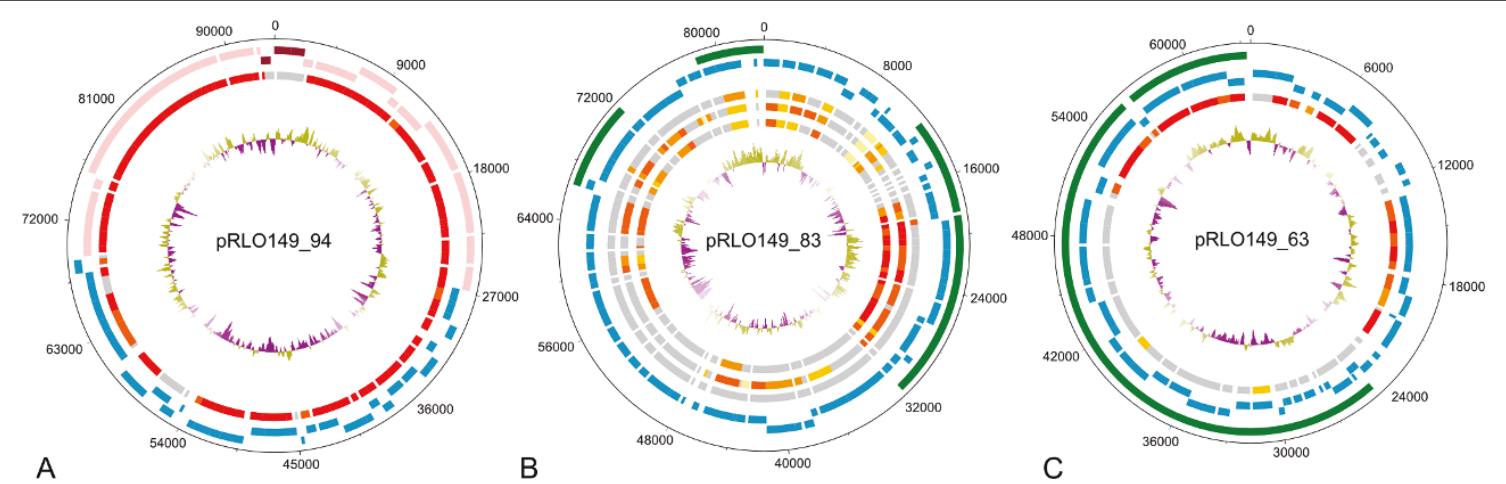

Figure 2 Circular plots of the plasmids of $\boldsymbol{R}$. Litoralis. A-C: The inner rings display the G+C-content with violet areas below average and olive areas above average. Orthologous ORFs in other organisms (red and grey bars) are according to the Needleman-Wunsch-algorithm. The shade of red illustrates the value of the algorithm with red bars representing the ORFs with the best conformity to the respective ORFs of $R$. litoralis and the grey bars showing the ORFs that have no orthologs in the respective organism. A: Plasmid pRLO149_94 of R.litoralis. Rings from the outside to the inside: 1 and 2: ORFs on the leading and complementary strands, respectively. Pink ORFs are associated with photosynthesis, blue ORFs have different functions, dark red ORFs show the replication genes of the plasmid. 3: orthologs in the genome of $R$. denitrificans. All orthologs can be found on the chromosome of $R$. denitrificans with $\sim 60 \mathrm{~kb}$ being syntenic. Only nine ORFs do not have orthologs in the genome of $R$. denitrificans including the replication genes of the plasmid. B: Plasmid pRLO149_83 of $R$. litoralis. Rings from the outside to the inside: 1: predicted alien genes on the plasmid; 2 and 3: ORFs on the leading and complementary strands of the plasmid, respectively; 4-6: orthologous ORFs in R. denitrificans, D. shibae and R. nubinhibens in the order of appearance. Nearly all orthologs in the two latter organisms are also encoded on plasmids. C: Plasmid pRL0149_63 of R. litoralis. Rings from the outside to the inside: 1: predicted alien genes on the plasmid; 2 and 3: ORFs on the leading and complementary strands of the plasmid, respectively; 4: orthologous ORFs in $R$. denitrificans. The orthologs in the genome of $R$. denitrificans are all located on the $69 \mathrm{~kb}$-plasmid of the organism. More than half of the plasmid encodes putative alien genes.

The genes downstream of the syntenic region to plasmid pRLO149_94 in $R$. denitrificans are also present in $R$. litoralis and are located approximately $100 \mathrm{~kb}$ upstream of $d n a A$. At the position on the chromosome of $R$. litoralis that corresponds to the position of the first gene associated with the photosynthesis apparatus of $R$. denitrificans (idi, RD1_0147) several transposases are encoded (Figure 1, upstream of island 10), suggesting this region to be a genomic hot spot. These findings suggest a translocation of the genetic material from the chromosome to the plasmid. This is further supported by the fact that photosynthesis genes are usually located

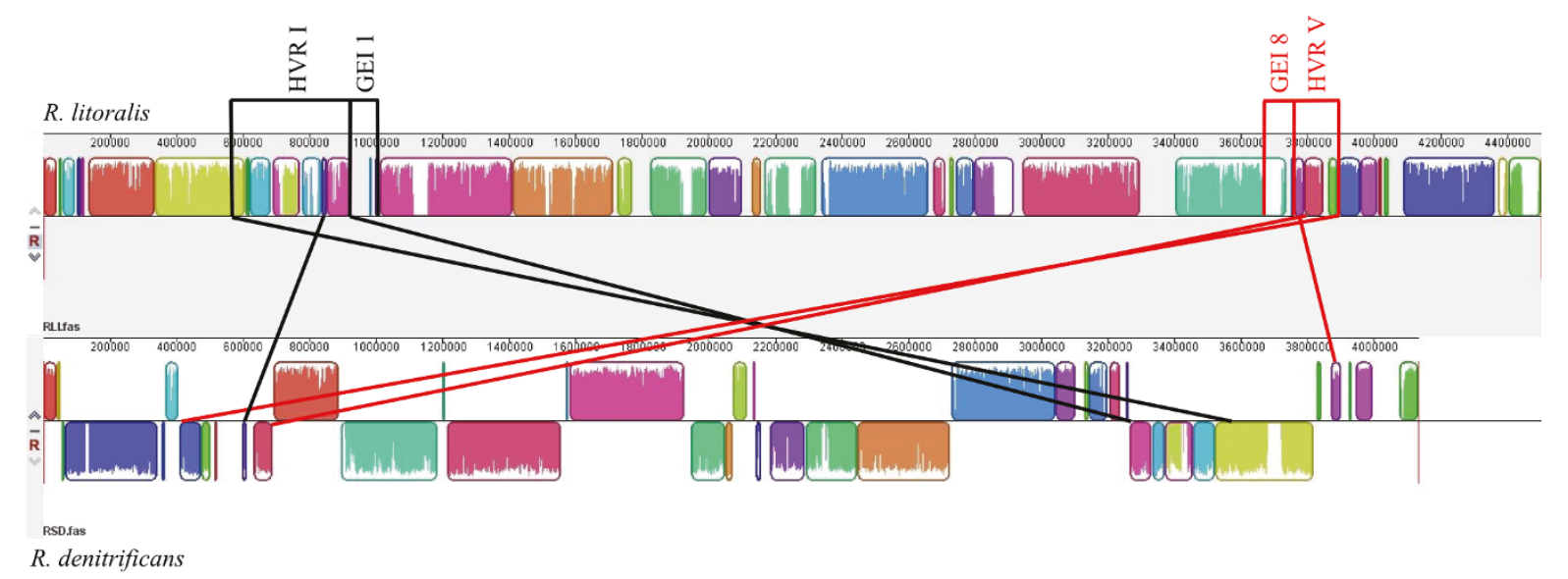

Figure 3 Mauve alignment of the chromosomes of $\boldsymbol{R}$. litoralis (upper line) and $\boldsymbol{R}$. denitrificans (lower line). Colored boxes represent syntenic regions and white/grey areas the unique regions of the two organisms. The two Roseobacter species share a high amount of genetic material but the chromosomes have been subject to frequent rearrangements and events of lateral gene transfer. Marked are two HVRs and the adjacent GEls of $R$. litoralis that have corresponding regions on similar positions of the chromosome of $R$. denitrificans. An X-like structure is formed when the HVRs are connected by lines. The areas display a mosaic-like structure of syntenic regions interspersed with unique regions in the respective organism. HVR I of $R$. litoralis contains a variety of genes that are connected to the association with the algal host of the bacterium, whereas HVR V contains genes for formaldehyde degradation and sugar metabolism. Both areas have little synteny with other Roseobacter clade members and are therefore important for the identification of genus-unique genes. 
Table 2 Heavy metal resistance genes encoded on plasmid pRL0149_83 of $R$. litoralis

\begin{tabular}{|c|c|c|c|}
\hline Accession No. & Gene Name & Annotation & Metal lons \\
\hline \multicolumn{4}{|c|}{ Copper oxidase systems } \\
\hline RLO149_p830810 & & copper resistance-like protein & $\mathrm{Cu}^{2+}$ \\
\hline RLO149_p830800 & & copper resistance-like protein & $\mathrm{Cu}^{2+}$ \\
\hline RLO149_p830790 & & putative copper resistance protein $\mathrm{A}$ & $\mathrm{Cu}^{2+}$ \\
\hline RLO149_p830650 & & copper resistance-like protein & $\mathrm{Cu}^{2+}$ \\
\hline RLO149_p830640 & & cupredoxin-like protein & $\mathrm{Cu}^{2+}$ \\
\hline RLO149_p830630 & & cupredoxin-like protein & $\mathrm{Cu}^{2+}$ \\
\hline \multicolumn{4}{|l|}{ CPx-type ATPases } \\
\hline RLO149_p830740 & actP & copper-transporting P-type ATPase (EC 3.6.3.4) & $\mathrm{Cu}^{+} / \mathrm{Ag}^{+}$ \\
\hline RLO149_p830520 & actP & copper-transporting P-type ATPase (EC 3.6.3.4) & $\mathrm{Cu}^{+} / \mathrm{Ag}^{+}$ \\
\hline RLO149_p830380 & & cation transport ATPase (P-type) family & $\mathrm{Zn}^{2+}$ \\
\hline \multicolumn{4}{|l|}{ HME-RND-proteins } \\
\hline RLO149_p830440 & & cation efflux system protein CusB-like protein & aerobically $\mathrm{Ag}^{+}$/anaerobically $\mathrm{Cu}^{+}$ \\
\hline RLO149_p830430 & CUSA & cation efflux system protein CusA & aerobically $\mathrm{Ag}^{+}$/anaerobically $\mathrm{Cu}^{+}$ \\
\hline RLO149_p830420 & CUSF & cation efflux system protein CusF & aerobically $\mathrm{Ag}^{+}$/anaerobically $\mathrm{Cu}^{+}$ \\
\hline \multicolumn{4}{|l|}{ CDF } \\
\hline RLO149_p830240 & & putative cobalt-zinc-cadmium resistance protein $\mathrm{CzcD}$ & $\mathrm{Zn}^{2+}$ \\
\hline \multicolumn{4}{|l|}{ Others } \\
\hline RLO149_p830340 & & putative ZIP Zinc transporter & $\mathrm{Zn}^{2+}$ \\
\hline RLO149_p830610 & & putative integral membrane protein DUF6 & $?$ \\
\hline
\end{tabular}

The proteins are categorized into different heavy metal efflux protein families. Based on sequence similarities the metal ions most likely transported by the efflux systems are indicated in column 4. HME-RND, Heavy Metal Efflux - Resistance-Nodulation-Cell division protein family; CDF, cation diffusion efflux proteins.

on the chromosomes of AAnPs [5] and are thought to be rather vertically than horizontally acquired genetic material in Roseobacter clade bacteria [23].

Comparison with other members of the Roseobacter clade To identify the genes specific for the genus Roseobacter, the genomes of both species were compared to 38 genomes of other Roseobacter clade bacteria. The results of the comparison are shown for two representatives of each phylogenetic subgroup of the Roseobacter clade outlined by Newton et al. [22] in Figure 1. Six hypervariable regions (HVR I-VI), areas of low conservation in the Roseobacter-clade, were found adjacent to the genomic islands predicted on the chromosome of $R$. litoralis (Figure 1). The HVRs of $R$. litoralis are characterized by a mosaic-like structure, with regions conserved in all Roseobacter clade bacteria alternating with genus-unique but also species-unique genes. Frequently, tRNAs were found flanking the HVRs, but not many transposases were present inside the areas indicating that the regions are permanently anchored in the chromosome [31]. The $\mathrm{G}+\mathrm{C}$-content and also the codon-adaptation index vary inside the HVRs.

Of special interest is HVR I as many genes identified in this area seem to be connected to the relation of $R$. litoralis to the algal host. For example, several genes for the degradation and transport of algal osmolytes like taurine (RLO149_c007790 - RLO149_c007880) and sarcosine (RLO149_c006600 - RLO149_c006630) were identified in HVR I. Furthermore, the genes for vitamin B12 biosynthesis (RLO149_c006160 - RLO149_c006260) are present. Vitamin B12 was shown to be important for the symbiosis of $D$. shibae with its dinoflagellate host [32]. A degradation pathway of erythritol is also located in HVR I (RLO149_c008260 - RLO149_c008410). The pathway is only present in $R$. litoralis and $R$. denitrificans and is known from Rhizobia [33,34]. In Rhizobium leguminosarum erythritol catabolism is important for competitiveness of the organism in the nodulation of pea plants [34]. Thus, erythritol catabolism might also be associated with the algal host relation of the Roseobacter species. The mosaic-like structure of HVR I resembles the symbiosis islands of Rhizobia [18,35]. Two different areas can be identified on the chromosome of $R$. denitrificans that correspond to HVR I of $R$. litoralis. In the alignment of the chromosomes of the two species, the HVRs of the two organisms form an X-like structure (Figure 3) which is probably due to the tendency of genes in closely related organisms to be located in the same distance from the origin [36].

Uncharacterized sugar and amino acid transporters are frequently found in the HVRs, e.g. in HVRs II and V. Genes for glucoside (RLO149_c021710 - RLO149_c021770) and galactose/arabinose (RLO149_c021930 - RLO149_c021980) transport and degradation as well as an arsenite resistance system 
(RLO149_c022030 - RLO149_c022040) are located in HVR III. The genes for sulfur oxidation (RLO149_c031760 - RLO149_c031920) and the denitrification genes (RLO149_c031300 - RLO149_c031570) were identified in HVR IV. Due to the lack of the nitrate reductase in $R$. litoralis the organism is not able to reduce nitrate; however, genes encoding all other enzymes required for denitrification are present. Thus, it is possible that the organism is able to reduce nitrite to molecular nitrogen under anoxic conditions. HVR V contains genes for formaldehyde degradation that are more common in the mixotrophic than in the heterotrophic group of Roseobacter clade members [22].

\section{rfb-genes and host association}

A $r f b$-gene cluster essential for the development of $\mathrm{O}$ antigens, i.e. lipopolysaccharides of the outer membranes of Gram-negative bacteria [37], was identified on plasmid pRLO149_63 of $R$. litoralis. Many of the Roseobacter clade bacteria have $r f b$-genes in their genomes and in about half of those the genes are located on plasmids. In $R$. denitrificans the $r f b$-gene cluster is encoded on a plasmid of $69 \mathrm{~kb}$ (pTB2), a size similar to pRLO149_63. Approximately $50 \%$ of the genes on pTB2 and pRLO149_63 are orthologs (Figure 2C). The remaining parts contain unique genes for each organism, and many of these are associated with cell envelope biosynthesis. These findings suggest that the plasmids are important for the cell surface structure of the two Roseobacter species and may have originated from a common ancestor.

In $E$. coli the $\mathrm{O}$-antigens are known to interact with the host defences and are therefore important virulence factors of pathogenic bacteria [37]. Many other Roseobacter clade bacteria with plasmid-located $r f b$-genes were also isolated from surfaces of algal or animal hosts. Therefore, we investigated whether a correlation between the replicon location of the $r f b$-genes and hostassociation exists. The genome sequences of marine Rhodobacterales species available in the IMG database $[38,39]$ were searched for $r f b$-genes and the replicon location was determined if possible (see Additional File 2 ). For the unfinished genomes, co-occurrence of plasmid replication genes with the $r f b$-genes on the same DNA-contig was regarded as an indicator for plasmid localisation. Chromosome location was confirmed by rRNA clusters or chromosome partitioning genes on the DNA-contigs that harbour the $r f b$-genes. In 24 of the 39 genomes $r f b$-genes were present and their location could be identified. Chromosomal $r f b$-genes were found in 12 organisms and 11 of those were isolated from the water column. Nine of the 12 plasmid-located $r f b$-gene clusters were found in organisms that were isolated either from host surfaces, aquacultures, algae blooms or the like. Thus, the replicon analysis of the $r f b$-genes of
20 of the 24 organisms supports the hypothesis that plasmid-location of the $r f b$-genes is coherent with hostassociation of Roseobacter clade bacteria.

\section{Photosynthesis}

To confirm the functionality of the plasmid-encoded photosynthesis apparatus in $R$. litoralis, the photosynthetic activity of the strain was measured via oxygen consumption (Figure 4). Whereas almost no reaction to light was observed during growth, cells in the stationary

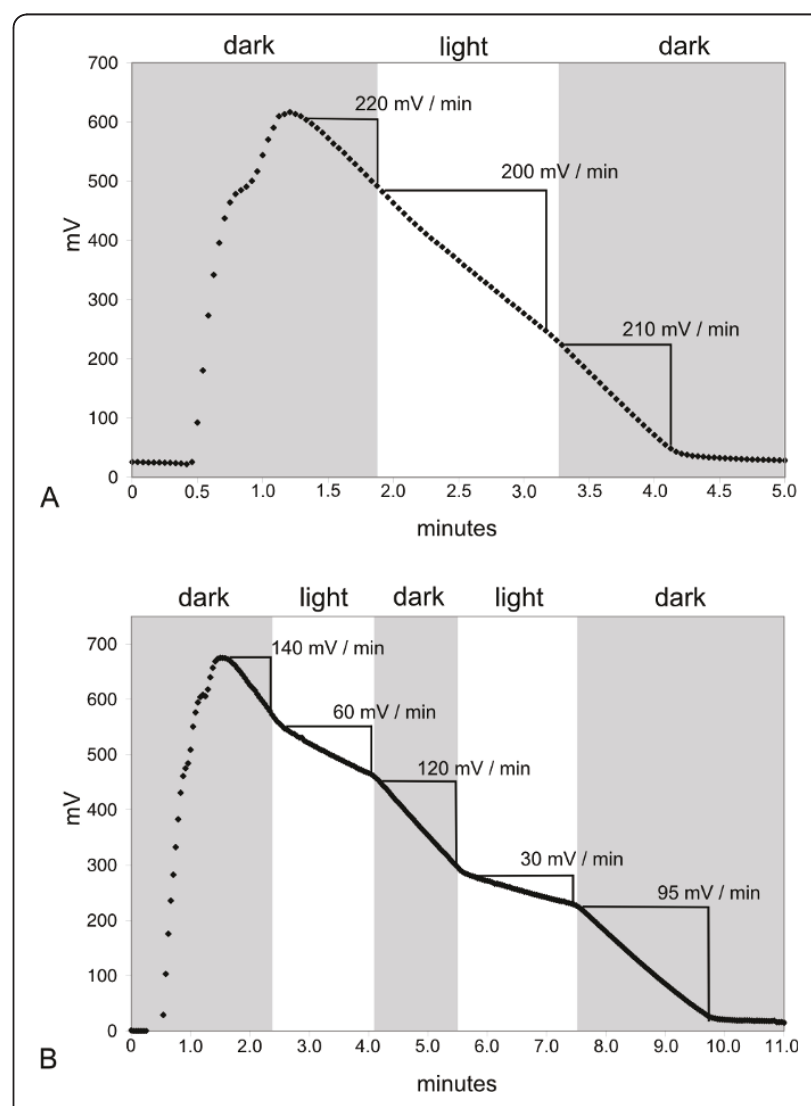

Figure 4 Respiration rates of $R$. litoralis cells. A: exponential growth phase; B: stationary growth phase. The values in $\mathrm{mV}$ $\mathrm{min}^{-1}$ indicate the respiration rates in the respective time intervals. Cells were kept anoxic under nitrogen gas until oxygen was supplied. At the beginning of each respiration measurement the cell suspension was saturated with oxygen and the oxygen consumption of the cells was measured in $\mathrm{mV} \mathrm{min}^{-1}$. The response of $R$. litoralis to light differs remarkably between the two growth phases. During the exponential growth phase the initial respiration rate in the dark was higher $\left(220 \mathrm{mV} \mathrm{min}{ }^{-1}\right)$ than in the stationary growth phase $\left(140 \mathrm{mV} \mathrm{min}^{-1}\right)$. When exposed to light, the cells that were in the exponential growth phase showed only a slight decrease to $200 \mathrm{mV} \mathrm{min}^{-1}$ (10\%) of the respiration rate whereas in the stationary phase culture the respiration rate was reduced to $43 \%\left(60 \mathrm{mV} \mathrm{min}^{-1}\right)$ of the original rate in the first light period and to $25 \%\left(30 \mathrm{mV} \mathrm{min}^{-1}\right.$ ) in the second. Cells resumed $95 \%$

(exponential growth phase) and 86\% (stationary growth phase) of their original respiration rate when darkened again. 
growth phase were highly responsive to light and showed a reduced respiration rate when exposed to light (Figure 4). Even though pigmentation occurred already during the exponential growth phase, the organism did not use the photosynthetic apparatus until the culture reached the stationary growth phase. The use, but not the expression, of the photosynthesis apparatus might therefore be influenced by nutrient availability in $R$. litoralis, as stationary phase cultures are nutrient depleted. We obtained similar results for $R$. denitrificans, with cells in the late stationary phase showing a stronger response to light than cells from the exponential growth phase (data not shown). For the alpha-Proteobacteria Labrenzia alexandrii DFl-11 and Hoeflea phototrophica DFL-43 periodic nutrient starvation has been reported to trigger bacteriochlorophyll- $a$ production whereas only slight effects were observed for $D$. shibae [40]. Obviously, the regulation mechanisms differ between the aerobic phototrophic bacteria and so does the architecture of their photosynthesis genes. In Additional File 3, the organization of the photosynthesis gene clusters of the organisms mentioned above is compared, showing that organisms with similar physiological traits also have similar gene organizations. The suggestion that the organization of genes within purple bacterial photosynthesis gene clusters reflects regulatory mechanisms, evolutionary history, and relationships between species was also made by other authors $[7,41,42]$. In the oligotrophic environment of the ocean, the use of the photosynthesis apparatus during nutrient depletion may be an important advantage for Roseobacter species in the competition with non-photosynthetic organisms.

\section{Substrate tests and pathway reconstruction}

Growth on different substrates was tested for $R$. litoralis to substantiate the reconstruction of metabolic pathways based on the genomic analyses. The results of the growth experiments are shown in Additional File 4. For each substrate the growth characteristics of $R$. litoralis and the genomic data were combined and the putative degradation pathways for the substrates allowing growth are shown in Figures 5 and 6. For the use of amino acids and amino acid derivatives, the predictions from the genome are mainly consistent with the experimentally achieved data (Additional File 4). However, for the degradation of sugars, sugar derivatives and algal osmolytes, genomic and experimental data differ in several cases (Additional File 4). Selected examples are discussed below.

\section{D-mannose and D-glucosamine}

For D-mannose and D-glucosamine the process of phosphorylation could not be revealed from the genomic data (Figure 5). In other bacteria, a phosphotransferase system (PTS) mediates phosphorylation of monosaccharides already during transport (for reviews see $[43,44]$ ). As for the majority of the Roseobacter clade members, no complete PTS is encoded in the genome of $R$. litoralis. Present are genes for an EIIA component, $\mathrm{Hpr}$ and HprK, but no permease was identified. The function of the incomplete PTS is to date unknown. It rather exhibits a regulatory function as proposed for the spirochaetes Treponema pallidum and Treponema denticola [45] and as shown for Sinorhizobium meliloti [46], which also lack the permease component of the PTS. Therefore, a PTS-independent system for transport and phosphorylation of D-mannose and $\mathrm{D}$-glucosamine must be present in $R$. litoralis.

\section{D-galactose, L-arabinose and D-fucose}

$R$. litoralis grew with $\mathrm{D}$-galactose, L-arabinose and Dfucose, but no complete pathways could be assigned to the degradation of these monosaccharides. A known mechanism for D-galactose degradation in bacteria is the DeLey-Doudoroff pathway (DD-pathway, [47]). Parts of the DD-pathway are encoded in the genome of $R$. litoralis, namely the genes coding for 2-dehydro-3-deoxygalactokinase (DgoK, RLO149_c015740) and 2-dehydro-3-deoxy-6phosphogalactonate aldolase (DgoA, RLO149_c015730). The other genes required for the degradation of D-galactose via the DD-pathway are not present in this gene cluster (cluster 1 , see Table 3 ). However, a gene with high similarity to galactose 1-dehydrogenase (Gal, RLO149_c021980) that catalyzes the first step of the pathway [47] was found elsewhere in the genome (cluster 2, see Table 3 ). This protein has also a high similarity to Larabinose 1-dehydrogenase of Azospirillum brasilense. In this organism a pathway for L-arabinose degradation was described that is analogue to the DD-pathway for galactose degradation [48-50]. Beside L-arabinose 1-dehydrogenase, also arabonate dehydratase of $A$. brasilense has an ortholog in $R$. litoralis (RLO149_c021970) which is also located in cluster 2 (Table 3 ). The other proteins of the pathway known in A. brasilense cannot be assigned to proteins of $R$. litoralis. Thus, both pathways are incomplete in $R$. litoralis; however, if the two clusters are combined, a degradation mechanism based on the DD-pathway may be functional for both sugars (Figure 5). Correspondingly, the regulators as well as the sugar-binding periplasmic protein of the transport system in cluster 2 are known to interact with D-galactose, L-arabinose and D-fucose [51-54], and also other enzymes are known to act on all three sugars $[55,56]$. As no mechanism for D-fucose degradation was identified in the genome of $R$. litoralis and only weak growth was observed with this sugar, it is possible that the enzymes also act on D-fucose but with a lower affinity.

\section{Glycogen}

$R$. litoralis was not able to grow with glycogen as a carbon source, probably due to the fact that no genes exist 


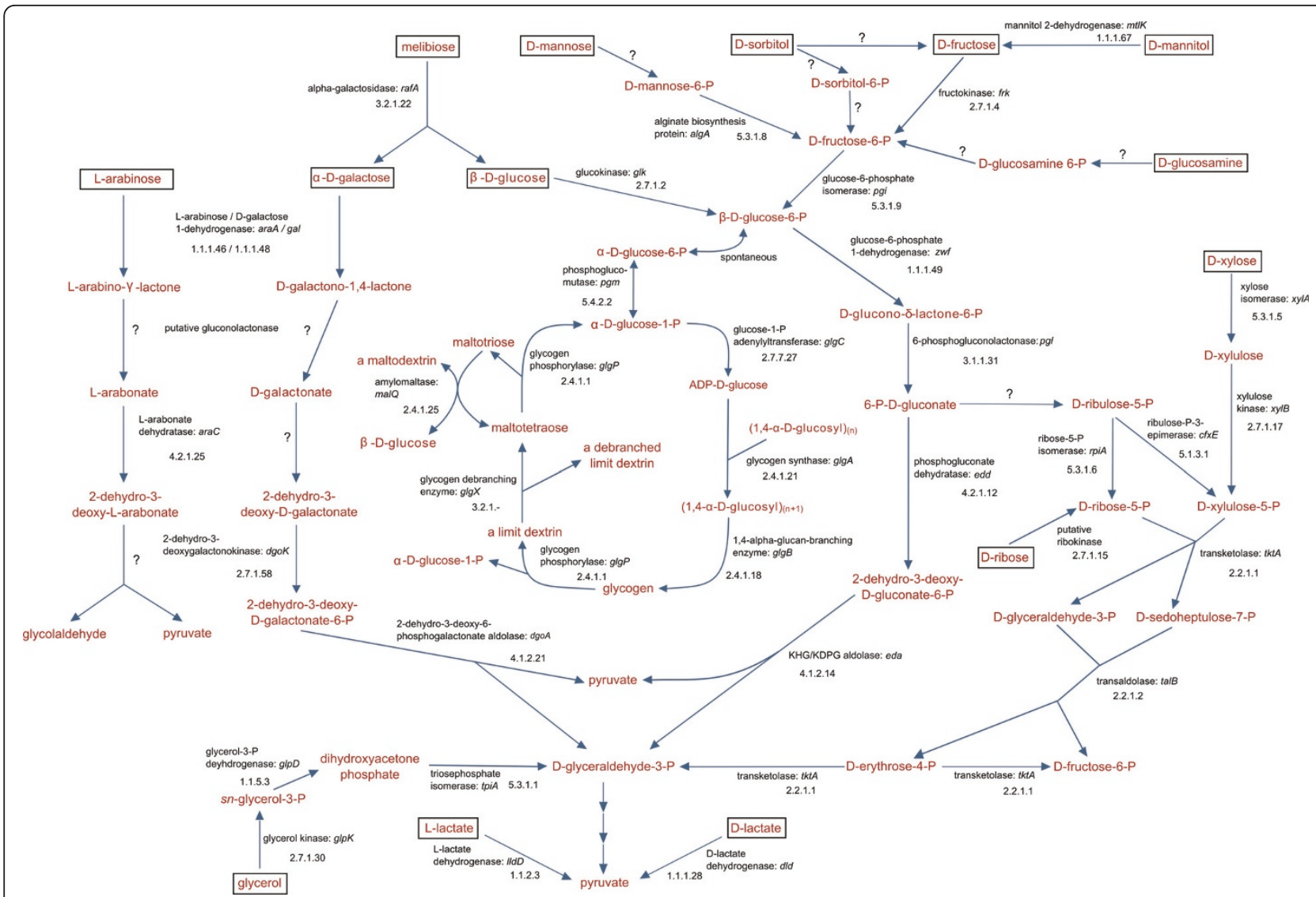

Figure 5 Predicted glycogen metabolism and catabolic pathways of sugars and sugar derivatives degraded by $R$. litoralis. The substrates that were used by $R$. litoralis as carbon sources in the experiments are framed. Metabolites are shown in red, enzyme and gene names as well as the EC numbers in black. If available, the corresponding gene names of the enzymes are given. Question marks indicate that no genes for the respective reaction were predicted from the genome of $R$. litoralis. If question marks are combined with enzyme names, the genes were not unambigously annotated and the given enzyme is proposed to be involved in the reaction.

in the predicted secretome coding for extracellular glycogen cleavage enzymes, and also no putative transporters for glycogen were identified. Intracellular glycogen, however, was detected in cells of both Roseobacter species when grown in mineral medium. In contrast, no glycogen formation was observed when the cells were grown in complex medium. The glycogen biosynthesis and degradation genes in the two organisms are therefore probably involved in intracellular glycogen production under limiting conditions. The proposed pathway for glycogen metabolism in $R$. litoralis is shown in Figure 5.

Glycogen formation is often induced by nitrogen starvation [57-59]; however, both Roseobacter species were not nitrogen-starved. Thus, another limiting factor must be the inducer of glycogen production in the mineral medium.

In contrast to the other Roseobacter clade members, in both Roseobacter species the genes for glycogen biosynthesis and degradation are co-located with essential genes of the ED-pathway. It is known from other studies that Roseobacter clade members use the ED-pathway for sugar breakdown $[60,61]$. The co-location of the genes coding for the ED-pathway with those of the glycogen biosynthesis and degradation indicates a close relation of the central carbon metabolism and glycogen storage in the Roseobacter species.

\section{Algal osmolytes}

The algal osmolytes tested in this study all served as carbon and nitrogen sources for both Roseobacter species, except for dimethylglycine. Additionally, $R$. litoralis used taurine as sulfur source. It was possible to reconstruct the pathways for algal osmolyte degradation from the genome of $R$. litoralis with the three exceptions creatinine, glycine betaine and putrescine (Figure 6, Additional File 4).

\section{Creatinine}

Whereas the degradation mechanism for creatinine is clear in $R$. denitrificans, in $R$. litoralis the enzyme 


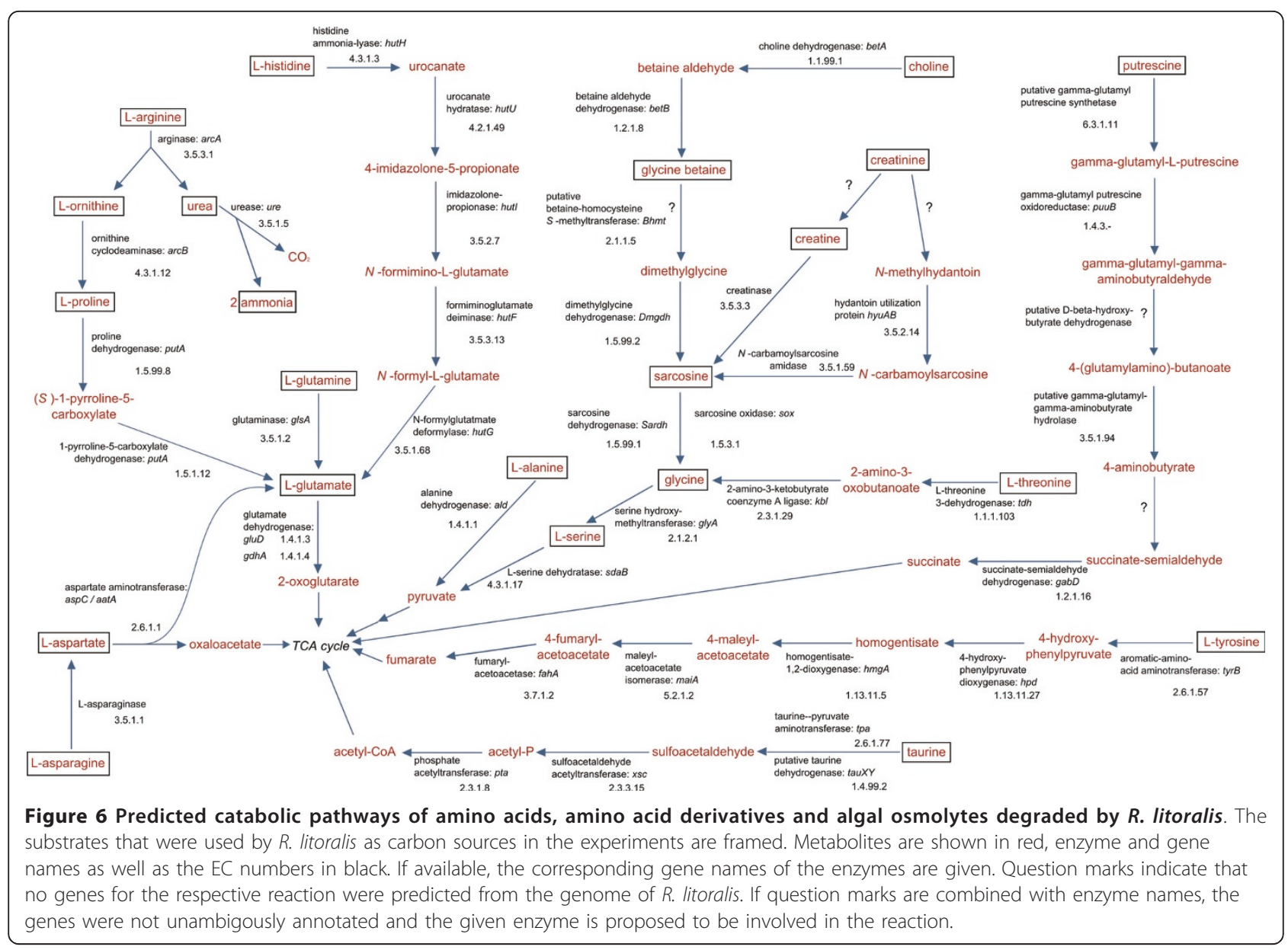

encoding the initial step of the pathway is not encoded in the genome (Figure 6). Nevertheless, no differences were observed between the two organisms when grown on creatinine. Furthermore, the enzymes mediating the second step of both possible pathways for creatinine degradation are present in the genome of $R$. litoralis (Figure 6). Thus, the organism is able to degrade creatinine, but the mechanism cannot be completely reconstructed from the genome.

\section{Glycine betaine}

The gene coding for the enzyme converting glycine betaine to dimethylglycine (betaine-homocysteine Smethyltransferase, BHMT) was not identified in the genomes of the two Roseobacter species. However, a potential candidate gene is RLO149_c039100 which is colocated with the genes for dimethylglycine dehydrogenase (DMGDH4, RLO149_c039110) and a sarcosine dehydrogenase (SARDH, RLO149_c039090) that are both directly involved in osmolyte degradation (Figure 6) and are annotated according to eukaryotic enzymes. The domain homocysteine S-methyltransferase (InterPro database [62], entry IPR003726) that was identified in the protein sequence of RLO149_c039100 is known to be part of mammalian BHMTs [63], but the predicted protein of $R$. litoralis shares only $26 \%$ identical amino acids with the mammalian enzymes (E-value 6e-09). A similar ORF (RD1_0018, 96\% identity to RLO149_c039100) is encoded in the genome of $R$. denitrificans that is located in the same genomic neighbourhood as RLO149_c039100.

Only eight bacterial enzymes annotated as BHMT are present in the UniProt database [64]. An enzyme of $S$. meliloti has been described to mediate this step in glycine betaine degradation [65], but the protein sequence of RLO149_c039100 shows only weak similarity to this protein. The genomic location, the functional domain and the fact that both Roseobacter strains are able to grow with glycine betaine as carbon and nitrogen sources point to RLO149_c039100 and RD1_0018 being involved in the degradation of glycine betaine in Roseobacters, representing a new class of bacterial BHMTs.

\section{Dimethylglycine}

Even though several genes coding for dimethylglycine dehydrogenases (DMGDH) were identified in the genomes of both Roseobacter species, the strains were 
Table 3 Putative galactose degradation gene clusters in R. litoralis

\begin{tabular}{|c|c|}
\hline Accession No. & Annotation \\
\hline \multicolumn{2}{|l|}{ Cluster 1} \\
\hline RLO149_c015710 & BgaB: beta-galactosidase 1 (EC 3.2.1.23) \\
\hline RLO149_c015720 & putative gluconolactonase \\
\hline RLO149_c015730 & $\begin{array}{l}\text { DgoA: 2-dehydro-3-deoxy-6-phosphogalactonate } \\
\text { aldolase (EC 4.1.2.21) }\end{array}$ \\
\hline RLO149_c015740 & $\begin{array}{l}\text { DgoK: 2-dehydro-3-deoxygalactonokinase (EC } \\
\text { 2.7.1.58) }\end{array}$ \\
\hline RLO149_c015750 & short chain dehydrogenase \\
\hline RLO149_c015760 & RafA: alpha-galactosidase (EC 3.2.1.22) \\
\hline RLO149_c015770 & $\begin{array}{l}\text { putative galactoside } A B C \text { transporter inner } \\
\text { membrane component }\end{array}$ \\
\hline RLO149_c015780 & $\begin{array}{l}\text { putative galactoside } A B C \text { transporter inner } \\
\text { membrane component }\end{array}$ \\
\hline RLO149_c015790 & putative extracellular galactoside-binding protein \\
\hline RLO149_c015800 & HTH-type transcriptional regulator, ICIR family \\
\hline RLO149_c015810 & $\begin{array}{l}\text { putative galactoside ABC transporter ATP- } \\
\text { binding protein }\end{array}$ \\
\hline \multicolumn{2}{|l|}{ Cluster 2} \\
\hline RLO149_c021930 & $\begin{array}{l}\text { putative HTH-type transcriptional regulator gbpR } \\
\text { (Galactose-binding protein regulator) }\end{array}$ \\
\hline RLO149_c021940 & SbpA: multiple sugar-binding periplasmic protein \\
\hline RLO149_c021950 & $\begin{array}{l}\text { putative multiple sugar transport ATP-binding } \\
\text { protein }\end{array}$ \\
\hline RLO149_C021960 & $\begin{array}{l}\text { putative multiple sugar transport permease } \\
\text { protein }\end{array}$ \\
\hline RLO149_c021970 & AraC: L-arabonate dehydratase (EC 4.2.1.25) \\
\hline RLO149_c021980 & Gal: D-galactose 1-dehydrogenase (EC 1.1.1.48) \\
\hline
\end{tabular}

neither able to utilize dimethylglycine (DMG) as carbon nor as nitrogen source. It is possible that the DMGDHs are only mediating the degradation of intracellular DMG derived from the cleavage of glycine betaine.

\section{Putrescine}

The degradation of the osmolyte putrescine is likely to occur via 4-aminobutyrate, as some of the genes of the pathway are present (Figure 6). However, the enzymes mediating step three and four of the pathway were not predicted in the genome of $R$. litoralis and also the aminotransferase responsible for the last step of the pathway, i.e. the degradation of 4-aminobutyrate to succinatesemialdehyde, was also not identified. Steps three and four might be mediated by RLO149_c025400 (putative gamma-glutamyl-gamma-aminobutyrate hydrolase) and RLO149_c025390 (putative D-beta-hydroxybutyrate dehydrogenase). The last step of the pathway might be carried out by one of the uncharacterized aldehyde aminotransferases encoded in the genome of $R$. litoralis.

\section{Taurine}

Two different pathways are postulated for the transport and degradation of taurine by microorganisms [66].
Apparently both pathways with different transport systems are present in $R$. litoralis. A taurine TRAP transport system in combination with a taurine dehydrogenase (TDH) also occurs in $R$. denitrificans, $D$. shibae, Rhodobacter sphaeroides and Paracoccus denitrificans, whereas a taurine $\mathrm{ABC}$ transporter and a taurine: pyruvate aminotransferase (Tpa) are present in most of the other genome sequenced Roseobacter clade members. Only $D$. shibae, $R$. denitrificans and $R$. litoralis have both uptake and degradation systems. Common features of these three organisms are their photosynthetic activity and the association with algal hosts $[1,4,32,67,68]$. The common feature of all taurine TRAP transporter-containing organisms is their ability to grow anaerobically [2,3,69-71]. The exception is $R$. litoralis, for which no anaerobic growth was reported yet. Nevertheless, the ability to grow anaerobically is indicated by the presence of genes for nitrite reduction (see above) and for dimethyl sulfoxide (DMSO)/TMAO reductases (RLO149_c007970, RLO149_c001820-RLO149_c001840). Anoxic conditions can occur during the collapse of algal blooms [72] which might also be the situation when high amounts of taurine and other algal osmolytes become available.

\section{Conclusions}

Our results show that the differences between the two Roseobacter species and the larger chromosome of $R$. litoralis are mainly due to events of horizontal gene transfer. Furthermore, the genomes have been subject to numerous genomic rearrangements. Plasmid pRLO149_94 of $R$. litoralis, on which the photosynthesis genes are encoded, was most likely translocated from the chromosome as it can almost completely be found on the chromosome of $R$. denitrificans. The photosynthetic activity of $R$. litoralis was shown to be growth-phase dependent. Whereas almost no reaction to light was observed during exponential growth, the organism was highly responsive to light during stationary growth phase. These results suggest a regulation of the photosynthetic activity according to nutrient availability that might also be reflected in the genetic organization of the photosynthesis genes. A plasmid with partial synteny to pRLO149_63 is present in R. denitrificans indicating a common ancestor of the two plasmids. Both plasmids and 11 other plasmids of Roseobacter clade bacteria harbour $r f b$-genes. The majority of these organisms were isolated from animal or algal hosts suggesting a coherence of plasmid location and host association. New mechanisms for sugar and algal osmolyte degradation were indicated. The ability to store intracellular glycogen as well as the utilization of algal osmolytes was reported for the first time for Roseobacter clade bacteria. Several pathways could not be fully elucidated, indicating $R$. litoralis to employ alternative enzymes compared to the known reference organisms. 


\section{Methods}

\section{Genome sequencing and finishing}

The strains $R$. litoralis OCh149 and $R$. denitrificans OCh114 were obtained from the German Collection of Microorganisms and Cell Cultures (DSMZ, Braunschweig Germany). The genome sequencing of $R$. litoralis was carried out at the J. Craig Venter Institute (Rockville, MD, USA) within the Microbial Genome Sequencing Project by a Sanger sequencing-based approach. For details see the Microbial Genome Sequencing Project [73]. The Sanger-based sequencing resulted in 7.97 coverage of the genome sequence. Gap closure and all manual editing steps were carried out at the Göttingen Genomics Laboratory (University of Göttingen, Germany) using the Gap4 (v 4.11) software of the Staden package [74]. Remaining gaps in the sequences were closed by primer walking on PCR products. Sequences were obtained using the Big Dye 3.0 chemistry (Applied Biosystems), customized sequencing primers and ABI3730XL capillary sequencers (Applied Biosystems).

\section{Gene prediction and annotation}

The prediction of coding sequences (CDS) or open reading frames (ORFs) was done with YACOP [75]. The results were verified and improved manually by using criteria such as the presence of a ribosome-binding site, GC frame plot analysis, and similarity to known proteinencoding sequences using the Sanger Artemis tool [76]. Functional annotation of all ORFs was carried out with the ERGO software package [77] (Integrated Genomics, Chicago, IL, USA). The protein sequences of the predicted ORFs were compared to the Swiss-Prot and TrEMBL databases [78]. Functional domains, repeats and important sites were analysed with the integrated database InterPro using the Web-based tool InterProScan [79].

\section{Comparative genomics}

The genomes of 38 Roseobacter clade members used for the comparison are the same as those used for the analysis of the $r f b$-genes and are listed in Additional File 2. Additionally, Roseobacter R2A57 and Loktanella sp. SE62 were included in the comparison. For comparative analysis, the BiBag software tool for reciprocal BLAST analyses as well as a global sequence alignment using the Needleman-Wunsch algorithm (pers. comm. Antje Wollherr and Heiko Liesegang, G2L Göttingen) was used. ORFs were considered as orthologs at a Needleman-Wunsch similarity-score of at least thirty percent and an E-value < 10e-21. Circular plots of DNA sequences were generated with the program DNAPlotter [80]. The comparative visualisation of the genetic organization of the photosynthesis genes of different organisms was realized with the GenVision software
(DNASTAR, Inc., Madison, WI, USA). Whole genome alignments were performed and visualized with the Mauve Software Tool [81].

\section{Sequence analysis}

The programs IslandViewer [82] and COLOMBO [83] were used for the detection of alien genes and genomic islands in the genomes of $R$. litoralis and $R$. denitrificans. To complete the computational prediction, the predicted regions were manually checked for elements commonly associated with GEIs like transposases, integrases, insertion sequence (IS)-elements, tRNAs and GC-content deviations [84]. For the prediction of the secretome of $R$. litoralis, PrediSi [85] was used.

The Codon Adaptation Index (CAI) measures the synonymous codon usage bias for a given DNA sequence by comparing the similarity between the synonymous codon usage of a gene and the synonymous codon frequency of a reference set. For the calculation of the CAI values the CAIcal server was used [86]. For the functional categorization of gene products, a BLAST search with all coding sequences was performed against the COG database [87].

The metabolic pathways were reconstructed with the Pathway Tools Software [88,89] from the BioCyc Database collection [90]. The pathways were manually curated if necessary.

\section{Measurement of photosynthetic activity}

$R$. litoralis was cultured in $500 \mathrm{~mL}$ Erlenmeyer flasks containing $200 \mathrm{~mL}$ of modified PPES-II medium [1] (see Additional File 5). Cells were grown at $25^{\circ} \mathrm{C}$ on a rotary shaker at $120 \mathrm{rpm}$ with a natural day-night-rhythm. After 40 hours of incubation (within the exponential growth phase) and 95 hours (stationary growth phase), respectively, the cultures were harvested by centrifugation $\left(7000 \mathrm{rpm}, 10^{\circ} \mathrm{C}, 15\right.$ minutes) and washed once with $100 \mathrm{~mL}$ of a salt solution containing $20 \mathrm{~g} / \mathrm{L} \mathrm{NaCl}$, $13 \mathrm{~g} / \mathrm{L} \mathrm{MgCl}_{2} \times 6 \mathrm{H}_{2} \mathrm{O}$ and $11.18 \mathrm{~g} / \mathrm{L} \mathrm{KCl}$. After an additional centrifugation step, the cell pellets were resuspended in $5 \mathrm{~mL}$ of the salt solution and the $\mathrm{OD}_{600}$ was adjusted to 10 . Respiration of the cells was measured via oxygen consumption [4].

\section{Heavy metal resistance tests}

The heavy metal resistance tests were carried out on agar plates based on a modified medium described by Shioi [91] (see Additional File 5). Heavy metal stock solutions were prepared as aqueous solutions of $50 \mathrm{mM}$ $\mathrm{CuCl}_{2} \times 2 \mathrm{H}_{2} \mathrm{O}$ and $\mathrm{O}_{4} \mathrm{SZn} \times 7 \mathrm{H}_{2} \mathrm{O}$, respectively, and sterile filtrated. The stock solutions were added to the autoclaved medium directly before pouring the plates. Each agar plate contained $20 \mathrm{~mL}$ of medium and 0.02 , $0.04,0.06,0.08$ or $0.1 \mathrm{mM}$ of one of the heavy metals. 
Tests were prepared in duplicates. Agar plates containing no heavy metals served as controls.

The pre-cultures were grown as follows: single colonies of the strains were transferred from agar plates to $20 \mathrm{~mL}$ of modified 70\% Marine Broth medium (MB, Difco 2216, see Additional File 5) in $100 \mathrm{~mL}$ Erlenmeyer flasks. Cells were grown at $22^{\circ} \mathrm{C}$ on a rotary shaker $(80$ rpm) with a natural day-night-rhythm to an optical density $(600 \mathrm{~nm})$ between 0.3 and 0.4 . The cell suspensions were diluted $10^{-4}$ fold and $800 \mu \mathrm{L}$ of the dilution were plated on each agar plate containing zinc or copper.

\section{Substrate tests}

Substrate tests were performed with $R$. litoralis to compare the experimental data with the genomic information. As genome comparisons of the two Roseobacter species revealed some putative differences, growth on algal osmolytes was tested for both organisms. All substrates tested as carbon, nitrogen or sulfur sources are listed in Additional File 4. Cells of $R$. litoralis and $R$. denitrificans were grown in sterile $22.5 \mathrm{~mL}$ metalcapped test tubes containing $5 \mathrm{~mL}$ of modified Marine Basal Mineral (MBM) medium [92] (see Additional File 5 ). Tests for taurine as sulfur source were carried out in modified MBM medium prepared without sulfate but with $100 \mu \mathrm{M}$ taurine. For the substrates that were tested as nitrogen sources, Tris- $\mathrm{HCl}$ in the modified $\mathrm{MBM}$ medium was replaced by $0.19 \mathrm{~g} / \mathrm{L} \mathrm{NaHCO}_{3}$ and no $\mathrm{NH}_{4} \mathrm{Cl}$ was added. The $\mathrm{pH}$ of the medium was adjusted to 7.5 after autoclaving with sterile $100 \mathrm{mM} \mathrm{HCl}$. Aqueous stock solutions of the substrates were prepared, sterile filtrated and stored at $-20^{\circ} \mathrm{C}$ or at $4^{\circ} \mathrm{C}$. Final concentrations for sugars, sugar derivatives, ethanol, glycogen and urea were $1 \mathrm{mg} / \mathrm{mL}, 2 \mathrm{mM}$ for amino acids and amino acid derivatives, $10 \mathrm{mM}$ for the algal osmolytes and $1 \mathrm{~mL} / \mathrm{L}$ for glycerol. When the substrates served as nitrogen sources, the final nitrogen concentration was adjusted to $2.5 \mathrm{mM}$. All tests were carried out in parallels, one additional parallel was not inoculated and served as a control. For all substrates that were tested as carbon sources for $R$. litoralis, two additional parallels were supplemented with $1 \%$ of complex medium (modified $70 \% \mathrm{MB}$, see Additional File 5) to investigate whether an additional cofactor was needed by the strain. The requirement for supplements to the mineral medium was also described for other Roseobacter clade bacteria $[93,94]$. The cultures were inoculated $(1 \% \mathrm{v} / \mathrm{v})$ with cells grown in liquid complex medium.

For the tests of nitrogen and sulfur sources, mannitol was used as carbon source for $R$. litoralis and glycerol for $R$. denitrificans, as growth of the organisms with these substrates yielded similar optical densities and no addition of complex medium was necessary to support growth. As inoculum for the nitrogen tests $200 \mu \mathrm{L}(4 \%$ $\mathrm{v} / \mathrm{v}$ ) of N-starved stationary phase cultures were used. All algal osmolytes that $R$. litoralis could use as carbon and nitrogen sources in separated experiments were additionally tested combined as carbon and nitrogen source within one experiment with a final concentration of $10 \mathrm{mM}$. In all tests, inoculated parallels that contained no carbon, nitrogen or sulfur source, respectively, served as negative controls. Growth was considered as positive if the optical density was higher than in the respective negative controls. All cultures were incubated at room temperature with a natural day-night-rhythm. At suitable time intervals the optical density at $600 \mathrm{~nm}$ $\left(\mathrm{OD}_{600}\right)$ was measured with a spectrophotometer (Bausch \& Lomb). After reaching the stationary phase, cells were transferred into fresh medium containing the respective substrate to confirm growth. When taurine served as sulfur source, the cells were transferred twice to fresh medium because the sulfur-free cultures were not growth limited compared to the parallels with taurine in the first two passages. After reaching the stationary phase in the second growth passage, purity of each culture was tested on an agar plate.

\section{Intracellular glycogen}

$R$. litoralis and $R$. denitrificans were tested for intracellular production of glycogen when grown in complex medium (modified 70\% MB, see Additional File 5) and in mineral medium using the method described by Bourassa and Camilli [57]. As mineral medium, modified $\mathrm{MBM}$ with $\mathrm{NaHCO}_{3}$ as buffer, $5 \mathrm{mM}$ ammonium and $1 \mathrm{mg} / \mathrm{mL}$ mannitol as carbon source $(1 \mathrm{~mL} / \mathrm{L}$ glycerol for $R$. denitrificans) was used. After growth the cells were pelleted, washed once with $1 \times$ PBS (phosphate buffered saline) buffer and stored frozen until further processing.

\section{Nucleotide sequence accession number}

The complete genome sequence of Roseobacter litoralis OCh149 was deposited in GenBank under the accession numbers [GenBank:CP002623]-[GenBank:CP002626].

\section{Additional material}

Additional file 1: Genes with assigned function that distinguish $R$. litoralis and $R$. denitrificans

Additional file 2: $r f b$-genes (antigen biosynthesis) in the genomes of marine Roseobacter clade members. The isolation sources are according to the information given in the IMG database [38]. Marked in blue are the exceptions, i.e. the organisms that were isolated from hosts but have chromosome-located $r f b$-genes and the pelagic organisms with plasmid-located rfb-genes.

Additional file 3: Comparison of the photosynthetic gene clusters of different anoxygenic phototrophs. The data for $\mathrm{H}$. phototrophica DFL-43 and L. alexandrii DFL-11 are based on the draft genome sequences. The gene organization of $R$. litoralis and $R$. denitrificans is identical, as is the case for $H$. phototrophica and $L$. alexandrii. The gene 
organization of $D$. shibae differs from the other two types. The two Roseobacter species show a similar, growth phase dependent response to light. H. phototrophica and L. alexandrii are not closely related but have a similar regulation of bacteriochlorophyll-a production, whereas the regulation mechanism of $D$. shibae is different [4]. Therefore, the gene organization and the location of the regulators may be important for the global regulation of the photosynthetic activity in aerobic anoxygenic phototrophic bacteria.

Additional file 4: Results from substrate tests with $R$. litoralis and predictions of substrate utilization from the genome. In bold are the substrates for which experimental and genomic data differ. -, OD600 equal or less than negative control; +, OD600 $<0.2 ;++$, OD600 $0.2-0.5$; ,+++ OD600 $>0.5 ; \mathrm{w}$, negative control $<\mathrm{OD} 600<0.2$. Results are shown for the second growth passage unless otherwise indicated. All amino acids had L-conformation, all sugars had D-conformation unless otherwise indicated. Growth on almost all sugars and sugar derivatives was considerably enhanced by the addition of $1 \%$ complex medium to the mineral medium. Glucose was not utilized without this supplementation. Addition of complex medium did not enhance the growth of $R$. litoralis on most amino acids. Exceptions were glutamate and the amino sulfonic acid taurine which were not utilized without supplementation.

\section{Additional file 5: Composition of Culture Media.}

\section{Acknowledgements and funding}

We thank Sarah Hahnke, Bert Engelen and Heribert Cypionka (Oldenburg) for their support with the measurement of photosynthetic activity and providing the equipment, Jörn Petersen (Braunschweig) for his advice on plasmid analysis, and Anne Buthoff (Göttingen), Kathleen Gollnow (Göttingen), Renate Gahl-Janßen (Oldenburg), Andrea Schlingloff (Oldenburg) and Birgit Kürzel (Oldenburg) for technical assistance. This study was supported by the niedersächsisches WW-Vorab "Comparative and functional genome analysis of representative members of the Roseobacter clade" (ZN2235), Germany, the Collaborative Research Center Roseobacter (TRR 51) funded by Deutsche Forschungsgemeinschaft, Germany, and the Marine Microbiology Initiative of the Moore Foundation, USA [95].

\section{Author details}

'Institute for Chemistry and Biology of the Marine Environment, University of Oldenburg, Carl-von-Ossietzky-Straße 9-11, 26129 Oldenburg, Germany. ${ }^{2}$ Göttingen Genomics Laboratory, Institute of Microbiology and Genetics, Georg-August University of Göttingen, Grisebachstraße 8, 37077 Göttingen, Germany.

\section{Authors' contributions}

DK performed the genome analysis, the experimental work and drafted the manuscript. ST analysed the genomic islands and helped to draft the manuscript. SV supervised the genome finishing, did the comparative studies, helped with the island prediction and was involved in drafting the manuscript. RL submitted the sequence data. HL did the assemblies of sequence data and helped with the finishing and annotation of the genome. AW provided the BiBag tool and helped with the BioCyc database for pathway reconstruction. RD and MS conceived of the study and helped to draft the manuscript. TB conceived of the study, supervised the experimental work and was involved in drafting the manuscript. All authors read and approved the final manuscript.

Received: 7 April 2011 Accepted: 21 June 2011 Published: 21 June 2011

\section{References}

1. Shiba T: Roseobacter litoralis gen. nov., sp. nov, and Roseobacter denitrificans sp. nov., aerobic pink-pigmented bacteria which contain bacteriochlorophyll-a. Syst Appl Microbiol 1991, 14:140-145.

2. Shioi Y, Doi M, Arata H, Takamiya K: A denitrifying activity in an aerobic photosynthetic bacterium, Erythrobacter sp. strain Och 114. Plant Cell Physiol 1988, 29:861-865.
3. Arata $\mathrm{H}$, Serikawa $\mathrm{Y}$, Takamiya K-i: Trimethylamine $\mathrm{N}$-oxide respiration by aerobic photosynthetic bacterium, Erythrobacter sp. OCh 114. J Biochem 1988, 103:1011-1015.

4. Holert J, Hahnke S, Cypionka H: Influence of light and anoxia on chemiosmotic energy conservation in Dinoroseobacter shibae. Environ Microbiol Rep 2010.

5. Pradella S, Allgaier M, Hoch C, Pauker O, Stackebrandt E, Wagner-Doebler I: Genome organization and localization of the pufLM genes of the photosynthesis reaction center in phylogenetically diverse marine Alphaproteobacteria. Appl Environ Microbiol 2004, 70:3360-3369.

6. Brinkhoff T, Giebel HA, Simon M: Diversity, ecology, and genomics of the Roseobacter clade: a short overview. Arch Microbiol 2008, 189:531-539.

7. Swingley WD, Sadekar S, Mastrian SD, Matthies HJ, Hao J, Ramos H, Acharya CR, Conrad AL, Taylor HL, Dejesa LC, Shah MK, O'Huallachain ME, Lince MT, Blankenship RE, Beatty JT, Touchman JW: The complete genome sequence of Roseobacter denitrificans reveals a mixotrophic rather than photosynthetic metabolism. J Bacteriol 2007, 189:683-690.

8. Silver S: Bacterial resistances to toxic metal ions - a review. Gene 1996, 179:9-19.

9. Silver S, Phung LT: Bacterial heavy metal resistance: new surprises. Annu Rev Microbiol 1996, 50:753-789.

10. Altug $\mathrm{G}$, Balkis $\mathrm{N}$ : Levels of some toxic elements and frequency of bacterial heavy metal resistance in sediment and sea water. Environ Monit and Assess 2009, 149:61-69.

11. Toes ACM, Finke N, Kuenen JG, Muyzer G: Effects of deposition of heavymetal-polluted harbor mud on microbial diversity and metal resistance in sandy marine sediments. Arch of Environ Contam Tox 2008, 55:372-385.

12. Al-Homaidan AA: Heavy metal concentrations in three species of green algae from the Saudi coast of the Arabian Gulf. J Food Agric Environ 2007, 5:354-358

13. Kalesh NS, Nair SM: Spatial and temporal variability of copper, zinc, and cobalt in marine macroalgae from the southwest coast of India. Bull Environ Contam Toxicol 2006, 76:293-300.

14. Hamdy AA: Biosorption of heavy metals by marine algae. Curr Microbiol 2000, 41:232-238.

15. Klerks PL, Weis JS: Genetic adaptation to heavy metals in aquatic organisms - a review. Environ Pollut 1987, 45:173-205.

16. Petersen J, Brinkmann H, Pradella S: Diversity and evolution of repABC type plasmids in Rhodobacterales. Environ Microbiol 2009, 11:2627-2638.

17. Osborn AM, Boeltner D: When phage, plasmids, and transposons collide: genomic islands, and conjugative- and mobilizable-transposons as a mosaic continuum. Plasmid 2002, 48:202-212.

18. Dobrindt U, Hochhut B, Hentschel U, Hacker J: Genomic islands in pathogenic and environmental microorganisms. Nat Rev Microbiol 2004, 2:414-424.

19. Mira A, Martin-Cuadrado AB, D'Auria G, Rodriguez-Valera F: The bacterial pan-genome: a new paradigm in microbiology. Int Microbiol 2010, 13:45-57.

20. Richardson JS, Hynes MF, Oresnik IJ: A genetic locus necessary for rhamnose uptake and catabolism in Rhizobium leguminosarum bv. trifolii. J Bacteriol 2004, 186:8433-8442.

21. Moran MA, Belas R, Schell MA, Gonzalez JM, Sun F, Sun S, Binder BJ, Edmonds J, Ye W, Orcutt B, Howard EC, Meile C, Palefsky W, Goesmann A, Ren Q, Paulsen I, Ulrich LE, Thompson LS, Saunders E, Buchan A: Ecological genomics of marine roseobacters. Appl Environ Microbiol 2007. 73:4559-4569.

22. Newton RJ, Griffin LE, Bowles KM, Meile C, Gifford S, Givens CE, Howard EC, King E, Oakley CA, Reisch CR, Rinta-Kanto JM, Sharma S, Sun SL, Varaljay V, Vila-Costa M, Westrich JR, Moran MA: Genome characteristics of a generalist marine bacterial lineage. ISME J 2010, 4:784-798.

23. Tang $\mathrm{K}$, Huang $\mathrm{HZ}$, Jiao NZ, Wu CH: Phylogenomic analysis of marine Roseobacters. PLoS One 2010, 5:e11604.

24. Cunliffe M: Correlating carbon monoxide oxidation with cox genes in the abundant marine Roseobacter clade. ISME J 2010.

25. Godfroid F, Taminiau B, Danese I, Denoel P, Tibor A, Weynants V, Cloeckaert A, Godfroid J, Letesson JJ: Identification of the perosamine synthetase gene of Brucella melitensis $16 \mathrm{M}$ and involvement of lipopolysaccharide $O$ side chain in Brucella survival in mice and in macrophages. Infect Immun 1998, 66:5485-5493.

26. Pena A, Teeling H, Huerta-Cepas J, Santos F, Yarza P, Brito-Echeverria J, Lucio M, Schmitt-Kopplin P, Meseguer I, Schenowitz C, Dossat C, Barbe V, 
Dopazo J, Rossello-Mora R, Schuler M, Glockner FO, Amann R, Gabaldon T, Anton J: Fine-scale evolution: genomic, phenotypic and ecological differentiation in two coexisting Salinibacter ruber strains. ISME J 2010, 4:882-895.

27. Medini D, Serruto D, Parkhill J, Relman DA, Donati C, Moxon R, Falkow S, Rappuoli R: Microbiology in the post-genomic era. Nat Rev Microbiol 2008, 6:419-430.

28. Huang $C$, Zhang $Y$, Jiao N: Phage resistance of a marine bacterium, Roseobacter denitrificans OCh114, as revealed by comparative proteomics. Curr Microbiol 2010.

29. Nies DH: Efflux-mediated heavy metal resistance in prokaryotes. FEMS Microbiol Rev 2003, 27:313-339.

30. Grass G, Fan B, Rosen BP, Franke S, Nies DH, Rensing C: ZitB (YbgR), a member of the cation diffusion facilitator family, is an additional zinc transporter in Escherichia coli. J Bacteriol 2001, 183:4664-4667.

31. Ullrich $S$, Kube M, Schubbe $S$, Reinhardt R, Schuler D: A hypervariable 130kilobase genomic region of Magnetospirillum gryphiswaldense comprises a magnetosome island which undergoes frequent rearrangements during stationary growth. J Bacteriol 2005, 187:7176-7184.

32. Wagner-Döbler I, Ballhausen B, Berger M, Brinkhoff T, Buchholz I, Bunk B, Cypionka H, Daniel R, Drepper T, Gerdts G, Hahnke S, Han C, Jahn D, Kalhoefer D, Kiss H, Klenk HP, Kyrpides N, Liebl W, Liesegang H, Meincke L, Pati A, Petersen J, Piekarski T, Pommerenke C, Pradella S, Pukall R, Rabus R, Stackebrandt E, Thole S, Thompson L, Tielen P, Tomasch J, von Jan M, Wanphrut N, Wichels A, Zech H, Simon M: The complete genome sequence of the algal symbiont Dinoroseobacter shibae: a hitchhiker's guide to life in the sea. ISME J 2010, 4:61-77.

33. Geddes BA, Pickering BS, Poysti NJ, Collins H, Yudistira H, Oresnik IJ: A locus necessary for the transport and catabolism of erythritol in Sinorhizobium meliloti. Microbiology 2010, 156:2970-2981

34. Yost CK, Rath AM, Noel TC, Hynes MF: Characterization of genes involved in erythritol catabolism in Rhizobium leguminosarum bv. viciae. Microbiology 2006, 152:2061-2074.

35. Gonzalez V, Bustos P, Ramirez-Romero MA, Medrano-Soto A, Salgado H, Hernandez-Gonzalez I, Hernandez-Celis JC, Quintero V, Moreno-Hagelsieb G, Girard L, Rodriguez O, Flores M, Cevallos MA, Collado-Vides J, Romero D, Davila G: The mosaic structure of the symbiotic plasmid of Rhizobium etli CFN42 and its relation to other symbiotic genome compartments. Genome Biol 2003, 4:R36.

36. Eisen JA, Heidelberg JF, White O, Salzberg SL: Evidence for symmetric chromosomal inversions around the replication origin in bacteria. Genome Biol 2000, 1:research00111-00119.

37. Whitfield C: Biosynthesis of lipopolysaccharide O-antigens. Trends Microbiol 1995, 3:178-185.

38. The IMG Database. [http://img.jgi.doe.gov/cgi-bin/w/main.cgi ].

39. Markowitz VM, Korzeniewski F, Palaniappan K, Szeto E, Werner G, Padki A, Zhao XL, Dubchak I, Hugenholtz P, Anderson I, Lykidis A, Mavromatis K, Ivanova N, Kyrpides NC: The integrated microbial genomes (IMG) system. Nucleic Acids Res 2006, 34:D344-D348.

40. Biebl H, Wagner-Döbler I: Growth and bacteriochlorophyll-a formation in taxonomically diverse aerobic anoxygenic phototrophic bacteria in chemostat culture: Influence of light regimen and starvation. Process Biochem 2006, 41:2153-2159.

41. Igarashi N, Harada J, Nagashima S, Matsuura K, Shimada K, Nagashima KVP: Horizontal transfer of the photosynthesis gene cluster and operon rearrangement in purple bacteria. J Mol Evol 2001, 52:333-341.

42. Yutin N, Beja O: Putative novel photosynthetic reaction centre organizations in marine aerobic anoxygenic photosynthetic bacteria: insights from metagenomics and environmental genomics. Environ Microbiol 2005, 7:2027-2033.

43. Barabote RD, Saier MH: Comparative genomic analyses of the bacterial phosphotransferase system. Microbiol Mol Biol Rev 2005, 69:608-634.

44. Postma PW, Lengeler JW, Jacobson GR: Phosphoenolpyruvate carbohydrate phosphotransferase systems of bacteria. Microbiol Rev 1993, 57:543-594.

45. Gonzalez CF, Stonestrom AJ, Lorca GL, Saier MH: Biochemical characterization of phosphoryl transfer involving HPr of the phosphoenolpyruvatedependent phosphotransferase system in Treponema denticola, an organism that lacks PTS permeases. Biochemistry 2005, 44:598-608.

46. Pinedo CA, Bringhurst RM, Gage DJ: Sinorhizobium meliloti mutants lacking phosphotransferase system enzyme HPr or EllA are altered in diverse processes, including carbon metabolism, cobalt requirements, and succinoglycan production. J Bacterio/ 2008, 190:2947-2956.

47. De Ley J, Doudoroff M: The metabolism of D-galactose in Pseudomonas saccharophila. J Biol Chem 1957, 227:745-757.

48. Watanabe S, Kodak T, Makino K: Cloning, expression, and characterization of bacterial L-arabinose 1-dehydrogenase involved in an alternative pathway of L-arabinose metabolism. J Biol Chem 2006, 281:2612-2623.

49. Watanabe S, Kodaki T, Makino K: A novel alpha-ketoglutaric semialdehyde dehydrogenase - Evolutionary insight into an alternative pathway of bacterial L-arabinose metabolism. J Biol Chem 2006, 281:28876-28888.

50. Watanabe S, Shimada N, Tajima K, Kodaki T, Makino K: Identification and characterization of L-arabonate dehydratase, L-2-keto-3-deoxyarabonate dehydratase, and L-arabinolactonase involved in an alternative pathway of L-arabinose metabolism - Novel evolutionary insight into sugar metabolism. J Biol Chem 2006, 281:33521-33536.

51. Van Bastelaere $E$, Lambrecht $M$, Vermeiren $H$, Van Dommelen A, Keijers V, Proost $P$, Vanderleyden J: Characterization of a sugar-binding protein from Azospirillum brasilense mediating chemotaxis to and uptake of sugars. Mol Microbiol 1999, 32:703-714.

52. Doty SL, Chang M, Nester EW: The chromosomal virulence gene, chvE, of Agrobacterium tumefaciens is regulated by a LysR family member. $J$ Bacteriol 1993, 175:7880-7886.

53. Kemner JM, Liang X, Nester EW: The Agrobacterium tumefaciens virulence gene $C h v E$ is part of a putative ABC-type sugar transport operon. $J$ Bacteriol 1997, 179:2452-2458.

54. Ankenbauer RG, Nester EW: Sugar-mediated induction of Agrobacterium tumefaciens virulence genes - structural specificity and activities of monosaccharides. J Bacteriol 1990, 172:6442-6446.

55. Zhu Y, Lin EC: An evolvant of Escherichia coli that employs the L-fucose pathway also for growth on L-galactose and D-arabinose. $J \mathrm{Mol}$ Evol 1986, 23:259-266.

56. Asada $Y$, Endo S, Inoue $Y$, Mamiya H, Hara A, Kunishima N, Matsunaga T: Biochemical and structural characterization of a short-chain dehydrogenase/reductase of Thermus thermophilus HB8: a hyperthermostable aldose-1-dehydrogenase with broad substrate specificity. Chem Biol Interact 2009, 178:117-126.

57. Bourassa L, Camilli A: Glycogen contributes to the environmental persistence and transmission of Vibrio cholerae. Mol Microbiol 2009, 72:124-138.

58. Ugalde JE, Parodi AJ, Ugalde RA: De novo synthesis of bacterial glycogen Agrobacterium tumefaciens glycogen synthase is involved in glucan initiation and elongation. Proc Natl Acad Sci USA 2003, 100:10659-10663.

59. Zevenhuizen LPTM: Cellular glycogen, beta-1,2-glucan, poly-betahydroxybutyric acid and extracellular polysaccharides in fast-growing species of Rhizobium. Antonie Van Leeuwenhoek 1981, 47:481-497.

60. Fürch T, Preusse M, Tomasch J, Zech H, Wagner-Doebler I, Rabus R, Wittmann C: Metabolic fluxes in the central carbon metabolism of Dinoroseobacter shibae and Phaeobacter gallaeciensis, two members of the marine Roseobacter clade. BMC Microbiol 2009, 9:209.

61. Zech H, Thole S, Schreiber K, Kalhofer D, Voget S, Brinkhoff T, Simon M, Schomburg D, Rabus R: Growth phase-dependent global protein and metabolite profiles of Phaeobacter gallaeciensis strain DSM 17395, a member of the marine Roseobacter-clade. Proteomics 2009, 9:3677-3697.

62. The InterPro Database. [http://www.ebi.ac.uk/interpro/].

63. Garrow TA: Purification, kinetic properties, and CDNA cloning of mammalian betaine-homocysteine methyltransferase. J Biol Chem 1996, 271:22831-22838.

64. The Uniprot Database. [http://www.uniprot.org/uniprot].

65. Barra L, Fontenelle C, Ermel G, Trautwetter A, Walker GC, Blanco C: Interrelations between glycine betaine catabolism and methionine biosynthesis in Sinorhizobium meliloti strain 102F34. J Bacteriol 2006, 188:7195-7204.

66. Cook AM, Denger K: Metabolism of taurine in microorganisms: a primer in molecular biodiversity? Adv Exp Med Biol 2006, 583:3-13.

67. Shiba T, Simidu U: Erythrobacter longus gen. nov., sp. nov., an aerobic bacterium which contains bacteriochlorophyll-a. Int J Syst Bacteriol 1982 32:211-217.

68. Biebl H, Allgaier M, Tindall BJ, Koblizek M, Lunsdorf H, Pukall R, WagnerDobler I: Dinoroseobacter shibae gen. nov., sp nov., a new aerobic phototrophic bacterium isolated from dinoflagellates. Int J Syst Evol Microbiol 2005, 55:1089-1096. 
69. Bamforth CW, Quayle JR: Aerobic and anaerobic growth of Paracoccus denitrificans on methanol. Arch Microbiol 1978, 119:91-97.

70. Pasternak C, Assemat K, Clement-Metral JD, Klug G: Thioredoxin is essential for Rhodobacter sphaeroides growth by aerobic and anaerobic respiration. Microbiology 1997, 143(Pt 1):83-91.

71. Shearer N, Hinsley AP, Van Spanning RJ, Spiro S: Anaerobic growth of Paracoccus denitrificans requires cobalamin: characterization of cobK and cobJ genes. J Bacteriol 1999, 181:6907-6913.

72. Sfriso A, Pavoni B, Marcomini A, Orio AA: Macroalgae, nutrient cycles, and pollutants in the Lagoon of Venice. Estuaries 1992, 15:517-528.

73. The Microbial Genome Sequencing Project. [http://camera.calit2.net/ microgenome/].

74. The Staden Package. [http://staden.sourceforge.net/].

75. Tech M, Merkl R: YACOP: Enhanced gene prediction obtained by a combination of existing methods. In Silico Biol 2003, 3:441-451.

76. Carver TJ, Rutherford KM, Berriman M, Rajandream MA, Barrell BG, Parkhill J: ACT: the Artemis comparison tool. Bioinformatics 2005, 21:3422-3423.

77. Overbeek R, Larsen N, Walunas T, D'Souza M, Pusch G, Selkov E, Liolios K, Joukov V, Kaznadzey D, Anderson I, Bhattacharyya A, Burd H, Gardner W, Hanke P, Kapatral V, Mikhailova N, Vasieva O, Osterman A, Vonstein V, Fonstein M, Ivanova N, Kyrpides N: The ERGO (TM) genome analysis and discovery system. Nucleic Acids Res 2003, 31:164-171.

78. The ExPASy Proteomics Server. [http://kr.expasy.org/ ]

79. Zdobnov EM, Apweiler R: InterProScan - an integration platform for the signature-recognition methods in InterPro. Bioinformatics 2001, 17:847-848.

80. Carver T, Thomson N, Bleasby A, Berriman M, Parkhill J: DNAPlotter: circular and linear interactive genome visualization. Bioinformatics 2009, 25:119-120.

81. Darling ACE, Mau B, Blattner FR, Perna NT: Mauve: Multiple alignment of conserved genomic sequence with rearrangements. Genome Res 2004, 14:1394-1403.

82. Langille MGl, Brinkman FSL: IslandViewer: an integrated interface for computational identification and visualization of genomic islands. Bioinformatics 2009, 25:664-665.

83. Waack S, Keller O, Asper R, Brodag T, Damm C, Fricke WF, Surovcik K, Meinicke P, Merkl R: Score-based prediction of genomic islands in prokaryotic genomes using hidden Markov models. BMC Bioinformatics 2006, 7:142.

84. Rocha EP: The organization of the bacterial genome. Annu Rev Genet 2008, 42:211-233.

85. Hiller K, Grote A, Scheer M, Munch R, Jahn D: PrediSi: prediction of signal peptides and their cleavage positions. Nucleic Acids Res 2004, 32: W375-W379.

86. Puigbò P, Bravo IG, Garcia-Vallve S: CAlcal: a combined set of tools to assess codon usage adaptation. Biol Direct 2008, 3:38.

87. Tatusov RL, Koonin EV, Lipman DJ: A genomic perspective on protein families. Science 1997, 278:631-637.

88. Karp PD, Riley M, Paley SM, Pellegrini-Toole A: The MetaCyc database. Nucleic Acids Res 2002, 30:59-61.

89. Karp PD, Riley M, Saier M, Paulsen IT, Collado-Vides J, Paley SM, PellegriniToole A, Bonavides C, Gama-Castro S: The EcoCyc database. Nucleic Acids Res 2002, 30:56-58.

90. The BioCyc Database Collection. [http://biocyc.org/]

91. Shioi Y: Growth characteristics and substrate specificity of aerobic photosynthetic bacterium, Erythrobacter sp. (Och 114). Plant Cell Physiol 1986, 27:567-572.

92. Geng H, Bruhn JB, Nielsen KF, Gram L, Belas R: Genetic dissection of tropodithietic acid biosynthesis by marine roseobacters. Appl Environ Microbiol 2008, 74:1535-1545.

93. Wagner-Döbler I, Rheims H, Felske A, Pukall R, Tindall BJ: Jannaschia helgolandensis gen. nov., sp nov., a novel abundant member of the marine Roseobacter clade from the North Sea. Int J Syst Evol Micr 2003, 53:731-738.

94. Wagner-Döbler I, Rheims H, Felske A, El-Ghezal A, Flade-Schorder D, Laatsch H, Lang S, Pukall R, Tindall BJ: Oceanibulbus indolifex gen. nov., sp nov., a North Sea alphaproteobacterium that produces bioactive metabolites. Int J Syst Evol Micr 2004, 54:1177-1184.

95. The Marine Microbiology Initiative of the Moore Foundation. [http:// www.moore.org/marine-micro.aspx].

96. The NCBI Database. [http://www.ncbi.nlm.nih.gov/]. doi:10.1186/1471-2164-12-324

Cite this article as: Kalhoefer et al: Comparative genome analysis and genome-guided physiological analysis of Roseobacter litoralis. BMC Genomics 2011 12:324.

\section{Submit your next manuscript to BioMed Central and take full advantage of:}

- Convenient online submission

- Thorough peer review

- No space constraints or color figure charges

- Immediate publication on acceptance

- Inclusion in PubMed, CAS, Scopus and Google Scholar

- Research which is freely available for redistribution

Submit your manuscript at www.biomedcentral.com/submit
C Biomed Central 